\title{
Management of Teachers' Social Skills and Job Performance in Senior Public Secondary Schools in Rivers State, Nigeria
}

\author{
P.C. Ukaigwe (Ph.D)*, I.F.Jack. Ph.D. \\ Department of Educational Management. Faculty of Education. University of Port Harcourt. Rivers State. \\ Nigeria
}

*Corresponding Author: P.C. Ukaigwe (Ph.D), Department of Educational Management. Faculty of Education. University of Port Harcourt. Rivers State. Nigeria

\begin{abstract}
The study investigated the relationship between management of teachers' social skills and job performance in public secondary school in Rivers State, Nigeria. Five research questions were answered with corresponding five hypotheses tested at 0.05 level of significance. The study was a correlation research with a population of 7,142 teachers from 274 public secondary schools in Rivers State, Nigeria. The sample size of the study is 714 teachers representing 10\% of the population. The simple random sampling technique was used to arrive at the sample. Face and content validated instruments titled Management of Teachers' Social Skills Scale (MTSSS) and Job Performance Scale (JPS) were used for data collection. Internal consistency reliability coefficients of 0.88 and 0.79 were computed for MTSSS and JPS respectively through Cronbach alpha. Simple and multiple regression were used to answer the research questions while $t$-test and ANOVA associated with simple and multiple regression were used to test the hypotheses at 0.05 level of significance. It was found that conflict resolution, interpersonal and problem-solving skills management are independent significant predictors of teachers' job performance apart from survival skills management that is not an independent predictor of job performance. Social skills management jointly significantly predicted teachers ' job performance. It was recommended that recreational centres should be created for the teachers by the school administrators in order to enlighten their social life. The teachers should develop self control in relating with other staff. Teachers should develop positive self relationship. Teachers should have a positive interpersonal relationship with members of staff.
\end{abstract}

Keywords: Management, Social Skills and Teaching Performance

\section{INTRODUCTION}

The functional adequacies of every formal and informal organization are to a high extent dependent on the managerial strategies and grids operational. It has been argued that the importance of management in the achievement of organizational goals and objectives is of the essence. Management could be seen as the act of organizing, coordinating, directing, supervising, inspecting, motivating and evaluating unit of activities in the achievement of stipulated goals and objectives. Management is defined as a process of controlling human and material resources for the attainment of organizational goals and objectives (Yagudah, 2018).It therefore implies that management is very indispensable in the existence of every organization as well as the school. The school is a formal setting where characters are molded, knowledge developed and skills acquired. School attainment helps one to develop cognitively, affectively and in the psychomotor domain.

School mostly at the secondary stage is very important in the achievement of literacy, numeracy and effective communication skills. Secondary education is that level of education immediately after the passage of primary schools unto the entrance into tertiary education. Secondary education is important because it enables one to gain entrance into the tertiary educational level for professionalization. It is presupposed that effective management of the school system is borne out of strict adherence to the goals and objectives of secondary education. Secondary educational system has lofty and functional goals and objectives that are enshrined in their National Policy of Education. The goals of education according to Federal Republic of Nigeria (2014:3) are the:

a. development of the individual into a morally sound, patriotic and effective citizens;

b. total integration of the individual into the immediate community, the Nigerian society and the world; 
c. provision of equal access to qualitative educational opportunities for all citizens at all levels of education, within and outside the formal school system;

d. inculcation of national consciousness, values and national unity; and

e. Development of appropriate skills, mental, physical and social abilities and competencies to empower the individual to live in and contribute positively to the society.

These goals of education cannot be fully implemented and achieved without being in specific terms. In specifics, the objectives of Post-Basic Education (secondary education) as enshrined in FRN, 2014: 17) are to:

a. provide holders of the Basic Certificate and Junior Arabic and Islamic Studies Certificate with opportunity for education of higher level irrespective of gender, social status, religious or ethnic background;

b. offer diversified curriculum to cater for the differences in talents, disposition, opportunities and future roles;

c. provide trained manpower in the applied sciences, technology and commerce at sub-professional grade;

d. provide entrepreneurial, technical and vocational job specific skills for sef-reliance, and for agricultural, industrial, commercial and economic development;

e. develop and promote Nigeria languages, art and culture in the context of wold's cultural heritage;

f. inspire students with desire for self-improvement and achievement of excellence;

g. foster patriotism, national unity and security education with emphasis on the common ties in-spite of our diversity; and

h. Raise morally upright and well-adjusted individuals who can think independently and rationally, respect the views and feelings of others and appreciate the dignity of labour.

The goals and objectives of education provide grounds for effective management of materials and human beings. In the management of materials, emphasis is laid of school facilities. These facilities range from residential, administrative and academic facilities. Management of residential facilities depicts the procurement, allocation and maintenance of hostel and its facilities in the school. Administrative facilities management cut across those facilities needed in the administrative blocks where non academic activities take place. On the other hand, academic facilities management is hinged on proper usage, supervision and inspection of teaching materials and facilities in the school. Management of human beings cut across recruitment, provision of welfare packages and development of skills. Skills management in the school could be emotional, intellectual or social skills. The present study concentrated on the management of social skills.

Social skills are those techniques and competences that regulate human relationship. They are those skills needed by a teacher to compliment the teaching methodology. Apart from the enormous importance attached to the emotional disposition of an individual, the social aspect of such individual is very important and sacrosanct. Human beings are social animals and require great skill in the association with others in order to reduce or eliminate rankles, chaos and disputes that may pose devastating dangers in the school and in the teaching process. Lack of social skills may inhibit collaboration, knowledge synergy and team teaching in the school. National Association of School Psychologist (NASP) (2002) stated that social skills manifest in the areas of survival skills, interpersonal skills, problem-solving skills and conflict resolution skills respectively.

Survival skills are those techniques that one adopts in an environment for survival sake. Survival skill has been defined as the acquisition of the basic skills needed in life (Joel, 2018). Survival skills management enables the teacher to manage the basic amenities available in the school environment. Abraham (2018) reported that survival skills acquisition prevents the teachers from moving around the community in search of basic amenities. The importance of skills acquisition in managing issues of life is of essence. Teachers who fail to develop problem-solving skills may end up being confused and devastated. Problem-solving skills are those skills that can help the teacher manage and control 
challenges in teaching (Adams, 2017). Most of the teachers do not possess the charisma to handle teaching and relationship problems. Teachers who develop little or no problem-solving skills are easily discouraged and as such lack concentration and composure in the classroom (Idowu, 2017).

It requires enough skills to manage conflicts in the workplace. Conflict resolution as the name implies is the settlement of issues of great worry among workers that can result to face-off (Ajibola, 2016). Conflict resolution skills are types of skills that should be managed and desired in secondary schools where there are teachers from different ethnic background, religious affiliation and different life experience and expositions. Most of the times, conflict arises as a result of poor interpersonal relationship. Interpersonal skills management is the ability to harmonize, relate and associate with friends and colleagues with little or no rankle (Joel, 2018). Interpersonal skills management incapacity has a negative consequence on job performance. There may be a link between social skills management and teachers performance.

Teachers require good human relationship development and management to function effectively and efficiently in their statutory activities in the school. Bullock (2013) saw job performance as that totality of an employees' conduct which he performs over a certain period of time. An employee in the performance of some duties in his workplace in relation to job specifications over a particular period may be assessed if he is really doing well or not. Campbell (1990) described job performance as something done by an employee or a person. This can be seen as a task, duty, responsibility or obligation in the workplace. Job performance therefore, is the act of accomplishing a task for which an individual or employee is employed for. Recently, it is widely agreed that job performance consists of complicated series of interacting variables pertaining to aspects of the job, the employee and the environment (Milkovich \& Wigdor, 1991). Job performance is usually associated with good and comfortable working conditions. It has been argued that social skills are associated with job performance. It is not yet certain on the extent social skills can jointly and independently predict teachers' job performance in secondary schools in Rivers State, Nigeria. This study therefore, investigated the extent to which social skills can jointly and independently predict teachers' job performance in secondary schools in Rivers State.

\section{Statement of the Problem}

Lack of teachers' social awareness and management may have caused unfriendly and hostile work environment. Administrators and teachers have been reported spending more time, energy and resources in emotional development and professional development programmes with little recourse on the importance of social skills. Lack of social skills may result in poor intrapersonal and interpersonal skills. When the teachers do not have the required social skills, it may lead to stress and burnout which are inimical to arduous academic activities. Social skills are highly needed because teaching and learning are founded on interaction. Without effective interaction, it may be almost impossible for learning to take place. It appears that teachers' do not properly manage their social skills for job performance. Hence the researchers are bothered and investigated the extent to which management of social skills can jointly and independently predicts teachers' job performance in Rivers State, Nigeria.

\subsection{Aim and Objectives of the Study}

The study was aimed at investigating the extent management of social skills can jointly and independently predict teachers' job performance in Rivers State, Nigeria. Specifically, the study sought to:

1. Find out the extent survival skills management can predict teachers' job performance in secondary schools in Rivers State, Nigeria.

2. Ascertain the extent interpersonal skills management can predict teachers' job performance in secondary schools in Rivers State, Nigeria.

3. Determine the extent problem-solving skills can predict teachers' job performance in secondary schools in Rivers State, Nigeria.

4. Establish the extent conflict resolution skills can predict teachers' job performance in secondary schools in Rivers State, Nigeria.

5. Determine the extent social skills management can jointly predict teachers' job performance in secondary schools in Rivers State, Nigeria. 


\subsection{Research Questions}

The following research questions were answered.

1. To what extent does survival skills management predict teachers' job performance in secondary schools in Rivers State, Nigeria?

2. What is the extent to which interpersonal skills management predict teachers' job performance in secondary schools in Rivers State, Nigeria?

3. To what extent does problem-solving skills management predict teachers' job performance in secondary schools in Rivers State, Nigeria?

4. What is the extent to which conflict resolution skills management predict teachers' job performance in secondary schools in Rivers State, Nigeria?

5. To what extent does social skills management jointly predict teachers' job performance in secondary schools in Rivers State, Nigeria?

\subsection{Hypotheses}

The following hypotheses were tested at 0.05 level of significance.

1. Survival skills management does not significantly predict teachers' job performance in secondary schools in Rivers State, Nigeria.

2. Interpersonal skills management does not significantly predict teachers' job performance in secondary schools in Rivers State, Nigeria.

3. Problem-solving skills management does not significantly predict teachers' job performance in secondary schools in Rivers State, Nigeria.

4. Conflict resolution skills management does not significantly predict teachers' job performance in secondary schools in Rivers State, Nigeria.

5. Social skills management does not significantly jointly predict teachers' job performance in secondary schools in Rivers State, Nigeria.

\section{Methodology}

The study was a correlation research with a population of 7,142 teachers from 274 public secondary schools in Rivers State, Nigeria. The sample size of the study is 714 teachers representing $10 \%$ of the population. The simple random sampling technique was used to arrive at the sample. Face and content validated instruments titled Management of Teachers' Social Skills Scale (MTSSS) and Job Performance Scale (JPS) were used for data collection. Internal consistency reliability coefficients of 0.88 and 0.79 were computed for MTSSS and JPS through Cronbach alpha. Simple and multiple regression were used to answer the research questions while t-test and ANOVA associated with simple and multiple regression were used to test the hypotheses at 0.05 level of significance.

\section{RESUlts}

Research question 1: To what extent does survival skills management predict teachers' job performance in secondary schools in Rivers State, Nigeria?

Table1. Simple regression on the extent of prediction of survival skills management on teachers' job performance in secondary schools in Rivers State

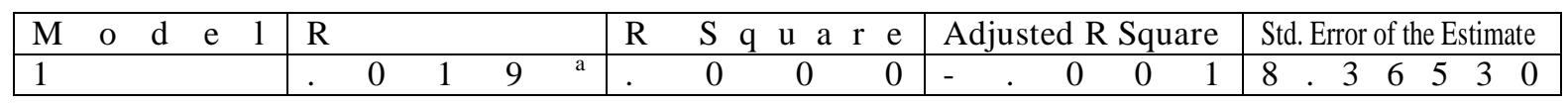

Table 1 revealed that the regression coefficients and regression square values are 0.019 and 0.000 . The extent of prediction is determined by multiplying the $\mathrm{R}^{2}$ value by $100 \%$. Therefore, survival skills management predicts teachers' job performance by $0 \%(0.000 \times 100)$. By implication, survival skills management predicts teachers' job performance by $0 \%$ which is to a low extent because it is below the average acceptable percentage of $50 \%$.

Research question 2: What is the extent to which interpersonal skills management predict teachers' job performance in secondary schools in Rivers State, Nigeria? 
Table2. Simple regression on the extent of prediction of interpersonal skills management on teachers' job performance in secondary schools in Rivers State

\begin{tabular}{|l|lllll|lllllll|lc|}
\hline Model & R & & & & R & S & q & u & a & r & e & Adjusted R Square \\
\hline 1 &. & 4 & 5 & 3 & ${ }^{a}$ &. & 2 & 0 & & 5 &. & 2 & 0 & 4 \\
\hline
\end{tabular}

Table 2 revealed that the regression coefficients and regression square values are 0.453 and 0.205 . The extent of prediction is determined by multiplying the $\mathrm{R}^{2}$ value by $100 \%$. Therefore, interpersonal skills management predicts teachers' job performance by $20.5 \%(0.205 \times 100)$. By implication, interpersonal skills management predicts teachers' job performance by $20.5 \%$ which is to a low extent because it is below the average acceptable percentage of $50 \%$.

Research question 3: To what extent does problem-solving skills management predict teachers' job performance in secondary schools in Rivers State, Nigeria?

Table3. Simple regression on the extent of prediction of problem-solving skills management on teachers' job performance in secondary schools in Rivers State

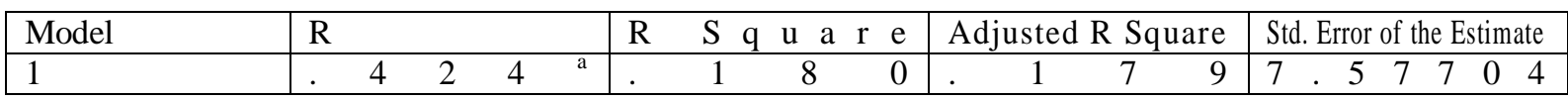

Table 3 revealed that the regression coefficients and regression square values are 0.424 and 0.180 . The extent of prediction is determined by multiplying the $\mathrm{R}^{2}$ value by $100 \%$. Therefore, problem-solving skills management predicts teachers' job performance by $18 \%(0.180 \times 100)$. By implication, problemsolving skills management predicts teachers' job performance by $18 \%$ which is to a low extent because it is below the average acceptable percentage of $50 \%$.

Research question 4: What is the extent to which conflict resolution skills management predict teachers' job performance in secondary schools in Rivers State, Nigeria?

Table4. Simple regression on the extent of prediction of conflict resolution skills management on teachers' job performance in secondary schools in Rivers State

\begin{tabular}{|c|c|c|c|c|c|c|c|c|c|c|c|c|}
\hline Model & $\mathrm{R}$ & & & & $\mathrm{R}$ & $\mathrm{S}$ & $\mathrm{u}$ & $\mathrm{r} e$ & Adjuste & $\mathrm{S}$ & & Std. Error of the Estimate \\
\hline 1 & 7 & 4 & 2 & a & . & 5 & 5 & 0 & 5 & 5 & 0 & 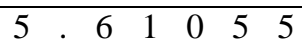 \\
\hline
\end{tabular}

Table 4 revealed that the regression coefficients and regression square values are 0.742 and 0.550 . The extent of prediction is determined by multiplying the $\mathrm{R}^{2}$ value by $100 \%$. Therefore, conflictresolution skills management predicts teachers' job performance by $55 \%(0.550 \times 100)$. By implication, conflictresolution skills management predicts teachers' job performance by $55 \%$ which is to a high extent because it is above the average acceptable percentage of $50 \%$.

Research question 5: To what extent does social skills management jointly predict teachers' job performance in secondary schools in Rivers State, Nigeria?

Table5. Multiple regression on the extent of prediction of social skills management on teachers' job performance in secondary schools in Rivers State

\begin{tabular}{|c|c|c|c|c|c|c|c|c|c|c|c|c|c|c|}
\hline $\mathrm{M}$ & o & $\mathrm{d}$ & $\mathrm{e}$ & 1 & $\mathrm{R}$ & & & & $\mathrm{R}$ & $\mathrm{S}$ & $\mathrm{q} \quad \mathrm{u} \quad \mathrm{a}$ & $\mathrm{r}$ & & Adjusted R Square \\
\hline 1 & & & & & 7 & 8 & 2 & a & & 6 & 1 & & 1 & 0 \\
\hline
\end{tabular}

Table 5 revealed that the regression coefficients and regression square values are 0.782 and 0.611 . The extent of prediction is determined by multiplying the $\mathrm{R}^{2}$ value by $100 \%$. Therefore, social skills management predicts teachers' job performance by $61.1 \%(0.611 \times 100)$. By implication, social skills management predicts teachers' job performance by $61.1 \%$ which is to a high extent because it is above the average acceptable percentage of $50 \%$.

Hypothesis 1: Survival skills management does not significantly predict teachers' job performance in secondary schools in Rivers State, Nigeria.

Table7. $t$-test associated with simple regression on the extent of prediction of survival skills management on teachers' job performance in secondary schools in Rivers State

\begin{tabular}{|c|c|c|c|c|c|c|c|c|}
\hline \multirow{2}{*}{\multicolumn{2}{|c|}{ Model }} & \multicolumn{2}{|c|}{$\begin{array}{l}\text { Unstandardized } \\
\text { Coefficients }\end{array}$} & $\begin{array}{l}\text { Standardized } \\
\text { Coefficients }\end{array}$ & \multirow[t]{2}{*}{$\mathbf{t}$} & \multirow[t]{2}{*}{$\begin{array}{l}\text { Probability } \\
\text { value }\end{array}$} & \multirow[t]{3}{*}{$\begin{array}{l}\text { Alpha } \\
\text { level }\end{array}$} & \multirow[t]{3}{*}{ Decision } \\
\hline & & B & Std. Error & Beta & & & & \\
\hline 1 & (Constant) & 40.647 & \begin{tabular}{lllll|}
1 &. & 4 & 5 & 9 \\
\end{tabular} & & 27.867 & $\begin{array}{lll}0 & 0 & 0 \\
\end{array}$ & & \\
\hline
\end{tabular}

International Journal of Humanities Social Sciences and Education (IJHSSE)

Page | 186 
Management of Teachers' Social Skills and Job Performance in Senior Public Secondary Schools in Rivers State, Nigeria

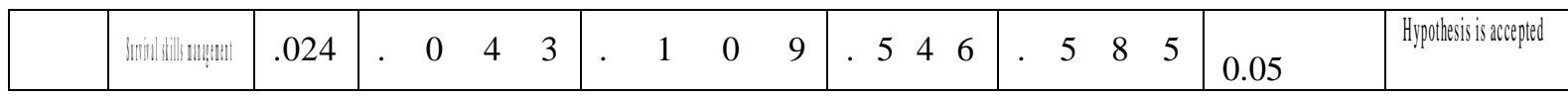

Table 7 revealed that the t-test value associated with simple regression is .546 which is not significant because the probability value of 0.585 is greater than alpha level of 0.05 . Therefore, the null hypothesis is accepted. This implies that survivalskills management does notsignificantly independently predict teachers' job performance in secondary schools in Rivers State.

Hypothesis 2: Interpersonal skills management does not significantly predict teachers' job performance in secondary schools in Rivers State, Nigeria.

Table8. $t$-test associated with simple regression on the extent of prediction of interpersonal skills management on teachers' job performance in secondary schools in Rivers State

\begin{tabular}{|c|c|c|c|c|c|c|c|c|}
\hline \multirow{2}{*}{\multicolumn{2}{|c|}{ Model }} & \multicolumn{2}{|c|}{$\begin{array}{l}\text { Unstandardized } \\
\text { Coefficients }\end{array}$} & \multirow{2}{*}{\begin{tabular}{|l|}
$\begin{array}{l}\text { Standardized } \\
\text { Coefficients }\end{array}$ \\
Beta \\
\end{tabular}} & \multirow[t]{2}{*}{$t$} & \multirow[t]{2}{*}{$\begin{array}{l}\text { Probability } \\
\text { value }\end{array}$} & \multirow[t]{2}{*}{$\begin{array}{l}\text { Alpha } \\
\text { level }\end{array}$} & \multirow[t]{2}{*}{\begin{tabular}{|l|} 
Decision \\
\end{tabular}} \\
\hline & & B & Std. Error & & & & & \\
\hline \multirow[t]{2}{*}{1} & $($ Constant $)$ & 75.465 & $\begin{array}{lll}3 & 8 & 6 \\
\end{array}$ & & 31.627 & $\begin{array}{lll}0 & 0 & 0 \\
\end{array}$ & & \\
\hline & 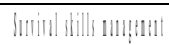 & -.958 & $\begin{array}{lll}0 & 6 & 7\end{array}$ & $\begin{array}{lll}4 & 5 & 3\end{array}$ & \begin{tabular}{|l|}
-14.353 \\
\end{tabular} & $\begin{array}{lll}0 & 0 & 0 \\
\end{array}$ & 0 & Hypothessis is rejected \\
\hline
\end{tabular}

Table 8 revealed that the t-test value associated with simple regression is -14.353 which is significant because the probability value of 0.000 is less than alpha level of 0.05 . Therefore, the null hypothesis is rejected. This implies that interpersonal skills management significantly independently predict teachers' job performance in secondary schools in Rivers State.

Hypothesis 3: Problem-solving skills management does not significantly predict teachers' job performance in secondary schools in Rivers State, Nigeria.

Table9. $t$-test associated with simple regression on the extent of prediction of problem-solving skills management on teachers' job performance in secondary schools in Rivers State

\begin{tabular}{|c|c|c|c|c|c|c|c|c|}
\hline \multirow{2}{*}{\multicolumn{2}{|c|}{ Model }} & \multicolumn{2}{|c|}{$\begin{array}{l}\text { Unstandardized } \\
\text { Coefficients }\end{array}$} & \multirow{2}{*}{$\begin{array}{l}\text { Standardized } \\
\text { Coefficients } \\
\text { Beta } \\
\end{array}$} & \multirow[t]{2}{*}{$\mathbf{t}$} & \multirow[t]{2}{*}{$\begin{array}{l}\text { Probability } \\
\text { value }\end{array}$} & \multirow[t]{2}{*}{$\begin{array}{l}\text { Alpha } \\
\text { level }\end{array}$} & \multirow[t]{2}{*}{ Decision } \\
\hline & & B & Std. Error & & & & & \\
\hline \multirow[t]{2}{*}{1} & $($ Constant $)$ & 71.931 & 2.323 & & 30.970 & $\begin{array}{lll}0 & 0 & 0\end{array}$ & & \\
\hline & 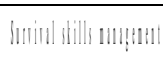 & -866 & $0 \quad 6 \quad 6$ & $\begin{array}{lll}4 & 2 & 4\end{array}$ & -13.222 & $\begin{array}{lll}0 & 0 & 0\end{array}$ & 05 & Hypothesis is rejected \\
\hline
\end{tabular}

Table 9 revealed that the t-test value associated with simple regression is 13.222 which is significant because the probability value of 0.000 is less than alpha level of 0.05 . Therefore, the null hypothesis is rejected. This implies that problem-solvingskills management significantly independently predict teachers' job performance in secondary schools in Rivers State.

Hypothesis 4: Conflict resolution skills management does not significantly predict teachers' job performance in secondary schools in Rivers State, Nigeria.

Table10. $t$-test associated with simple regression on the extent of prediction of conflict resolution skills management on teachers' job performance in secondary schools in Rivers State

\begin{tabular}{|c|c|c|c|c|c|c|c|c|}
\hline \multirow{2}{*}{\multicolumn{2}{|c|}{ Model }} & \multicolumn{2}{|c|}{$\begin{array}{l}\text { Unstandardized } \\
\text { Coefficients }\end{array}$} & \multirow{2}{*}{\begin{tabular}{|l|}
$\begin{array}{l}\text { Standardized } \\
\text { Coefficients }\end{array}$ \\
Beta \\
\end{tabular}} & \multirow[t]{2}{*}{$\mathbf{t}$} & \multirow[t]{2}{*}{$\begin{array}{l}\text { Probability } \\
\text { value }\end{array}$} & \multirow[t]{2}{*}{$\begin{array}{l}\text { Alpha } \\
\text { level }\end{array}$} & \multirow[t]{2}{*}{ Decision } \\
\hline & & B & Std. Error & & & & & \\
\hline \multirow[t]{2}{*}{1} & $($ Constant $)$ & 76.979 & 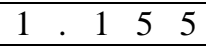 & & 66.620 & $\begin{array}{ll}0 & 0 \\
\end{array}$ & & \\
\hline & 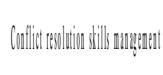 & -1.055 & $\begin{array}{lll}0 & 3 & 4\end{array}$ & $-\quad .742$ & -31.232 & $\begin{array}{ll}0 & 0\end{array}$ & 0.05 & Hypothesis is rejected \\
\hline
\end{tabular}

Table 10 revealed that the t-test value associated with simple regression is 31.232 which is significant because the probability value of 0.000 is less than alpha level of 0.05 . Therefore, the null hypothesis is rejected. This implies that conflict resolution skills management significantly independently predict teachers' job performance in secondary schools in Rivers State.

Hypothesis 5: Social skills management does not significantly jointly predict teachers' job performance in secondary schools in Rivers State, Nigeria. 
Table11. ANOVA associated with multiple regression on the extent of prediction of social skills management on teachers' job performance in secondary schools in Rivers State

\begin{tabular}{|c|c|c|c|c|c|c|c|c|c|}
\hline Model & Sum of Squares & $\mathrm{D} \quad \mathrm{f}$ & Mean Squz & & $\mathrm{F}$ & Probability value & Alpha level & Decision & \\
\hline \multirow[t]{3}{*}{1} & Regression & 34106.085 & & 5 & 6821.217 & 249.418 & $.000^{\mathrm{b}}$ & 0.05 & Hypothersis srepteded \\
\hline & Residual & 21687.382 & 79 & 3 & 27.349 & & & & \\
\hline & To t a 1 & 55793.467 & 79 & 8 & & & & & \\
\hline
\end{tabular}

Table 11 revealed that the $\mathrm{F}$ value associated with multiple regression is 249.418 which is significant because the probability value of 0.000 is less than alpha level of 0.05 . Therefore, the null hypothesis is rejected. This implies that socialskills management significantly jointly predictedteachers' job performance in secondary schools in Rivers State.

\section{DISCUSSION OF FINDINGS}

\subsection{Survival Skills Management and Teachers' Job Performance}

The study revealed that survival skills management predicted teachers' job performance to a low extent. It was also revealed that survival skills management does not significantly predict teachers' job performance in secondary schools in Rivers State, Nigeria. The low prediction of survival skills is irrespective of its importance in fast adaptation and acclimatization in the environment. The finding of the study is contrary to that of Joe (2018) who found that survival skills significantly relate with lecturers job productivity. The point of departure from the finding of this study and that of Joel could be because the respondents differed significantly. It is worthy to note that survival skills management enables the teacher to manage the basic amenities available in the school environment. In support of the finding of this study is Abraham (2018) who reported that survival skills acquisition hinder teachers breakthrough in their instructional achievement.

\subsection{Conflict Resolution Skills Management and Teachers' Job Performance}

The study revealed that conflict skills management is a significant predictor of teachers' job performance in secondary schools in Rivers State, Nigeria. It requires skills to manage conflicts in the workplace. Conflict does not allow tranquility and serenity in the workplace. Conflict resolution is expedient in the settlement of issues of great worry among workers that can result to face-off (Ajibola, 2016). When there is face-off among the teachers collaboration, synergy and team teaching may not be achieved. Conflict resolution skills are types of skills that should be managed and desired in secondary schools where their teachers from different ethnic background, religious affiliation and different life experience and expositions. There is a link between social skills management and teachers performance in secondary schools in Rivers State. This technique requires good human relationship development and management to function effectively and efficiently in their statutory activities in the school.

\subsection{Problem-Solving Skills Management and Teachers' Job Performance}

The study revealed that problem-solving skills management is a significant predictor of teachers' job performance in secondary schools in Rivers State, Nigeria. The importance of skills acquisition in managing issues of life is of essence. Teachers who fail to develop problem-solving skills may end up being confused and devastated. Buttressing the finding of this study was Adams (2019) who found that problem-solving skills are very important in class room management and control. The issue of problem-solving skills is very important because teachers who do not possess the charisma to handle teaching and relationship problems may end up achieving little in their instructional areas. The importance of problem-solving skill is stemming from the fact that teachers who develop little or no problem-solving skills are easily discouraged and as such lack concentration and composure in the classroom (Idowu, 2017).

\subsection{Interpersonal Skills Management and Teachers' Job Performance}

The study revealed that interpersonal skills management is a significant predictor of teachers' job performance in secondary schools in Rivers State, Nigeria. Most of the times, conflict arises as a result of poor interpersonal relationship. Interpersonal is very much required because it is the type of 
relationship that involves more than one person in the scene and as such requires great social skills and competences. Human beings are difficult to manage and control and as such requires a good working relationship in order to encourage imitation and modeling. Interpersonal skills management enables the teachers to harmonize, relate and associate with friends and colleagues with little or no rankle (Joel, 2018). Interpersonal skills management incapacity has a negative consequence on job performance. In a similar development with the finding of this study was Wu (2008) who reported that social skills successfully predict organizational citizenship behaviour and job performance.

\subsection{Social Skills Management and Teachers' Job Performance}

The study revealed that social skills management is a significant joint predictor of teachers' job performance in secondary schools in Rivers State, Nigeria. The finding corroborate with Wu (2008) who found that social skills can facilitate interpersonal interactions which can in turn lead to effective job outcomes. The reason why social skills predicted teachers' job performance is because they are those techniques and competences that regulate human relationship. The teachers have to effectively and efficiently interact with their students, colleagues and other associates, therefore, this requires great details of skills to get that done. Social skills are highly needed skills by the teacher to compliment the teaching methodology. Apart from the enormous importance attached to the emotional disposition of an individual, the social aspect of such individual is very important and sacrosanct. Human beings are social animals and require great skill in the association with others in order to reduce or eliminate rankles, chaos and disputes that may pose devastating dangers in the school and in the teaching process as well as profession (Joel, 2018). Lack of social skills may inhibit collaboration, knowledge synergy and team teaching in the school.

\section{CONCLUSION}

Based on the findings of this study, it was concluded that proper management of teachers' social skills in the areas of survival skills, interpersonal skills, conflict resolution skills and problem-solving skills can inevitably significantly predict teachers' job performance in secondary schools in Rivers State, Nigeria.

\section{RECOMMENDATIONS}

The following recommendations were made in this study.

1. Recreational centres should be created for the teachers by the school administrators in order to enlighten their social life.

2. The teachers should develop self control in relating with other staff.

3. Teachers should have a positive interpersonal relationship with members of staff.

4. Teachers should address issues arising from quarrels with immediate attention.

\section{REFERENCES}

[1] Abraham, O.I. (2018). Teachers' survival skills development and effective classroom control. Journal of Educational Issues, 1(1), 1-17.

[2] Adams, U.K. (2017). Teachers' problem-solving techniques and teaching effectiveness in secondary schools in Rivers State. Journal of Sociology, 1(1), 14-21.

[3] Ajibola, I.T. (2016). Industrial conflict management panaceas. Owerri: Ido Printing Press.

[4] Bullock, R. (2013).Job performance defined-Personal development. Retrieved from www.Scontrinopowell.com

[5] Campbell, J.P. (1990). Modelling the performance prediction problem in industrial and organizational psychology.In M.D. Dunnette \& L.M. Hough (Eds.).Handbook of industrial and organizational psychology, 1, 687-732.Palo Alto: Consulting Psychologist Press.

[6] Federal Republic of Nigeria. (2014). National Policy on Education $6^{\text {th }}$ edition. Abuja: Nigerian Educational Research and Development Council.

[7] Idowu, S.L. (2017). Problem-solving skills and teaching confidence among secondary school teachers in Ekiti State, Nigeria. Journal of Sociology, 1(1), 1-13.

[8] Joel, I.Y. (2018). Impact of survival skills and teachers job satisfaction. Journal of Educational Issues, 1(1), $18-22$. 
[9] Milkovich, G.T. \& Wigdor, A.K. (1991). Pay for performance: Evaluating performance appraisal and merit pay. Washington: National Academy Press.

[10] National Association of School Psychologists (NASP) (2002). Social skills: Promoting positive behaviour, academic success and school safety. Retrieved from https://www.naspcenter.org/factsheets /socialskills_ fs.html.

[11] Wu, Y. (2008). Social skills in the workplace: What is social skills and how does it matter? Published Thesis, Department of Business Administration, University of Missouri-Columbia. Retrieved from https://mospace.umsystem.edu.

[12] Yagudah, M.O. (2018). Management approaches and organizational performance. Aba: Uphosco Publisher

Citation: P.C. Ukaigwe (Ph.D)*, I.F.Jack. Ph.D. " Management of Teachers' Social Skills and Job Performance in Senior Public Secondary Schools in Rivers State, Nigeria " International Journal of Humanities Social Sciences and Education (IJHSSE), vol 7, no. 4, 2020, pp. 182-190. doi: http://dx.doi.org/10.20431/2349-0381.0704019.

Copyright: (C) 2020 Authors. This is an open-access article distributed under the terms of the Creative Commons Attribution License, which permits unrestricted use, distribution, and reproduction in any medium, provided the original author and source are credited. 